Gut, 1973, 14, 209-212

\title{
Hypoxia and asymmetrical fibrosis of the liver in children
}

\author{
M. L. GHOSH AND J. L. EMERY \\ From the Department of Pathology, Children's Hospital, Sheffield
}

SUMMARY The liver in children contains a greater amount of connective tissue in relation to parenchymal tissue than in adults and there is often more in the left than in the right lobe. Livers from 150 children who died between birth and 12 years of age, under different circumstances, were studied.

The findings suggested that hypoxia was an important factor leading to increase in fibrous tissue in children's livers. Children who had cyanosis at birth and prolonged hypoxia associated with pathological conditions showed the highest ratio of connective tissue to liver parenchyma. The predominant non-hepatic lesions found were cyanotic congenital heart disease, coarctation of the aorta, acute respiratory distress, congenital malformation of the central nervous system, and shock after abdominal surgery.

The liver consists of two physiological lobes which differ from the anatomical demarcation (Cantlie, 1897-1898; Mall, 1906). Asymmetrical changes in two lobes of the liver have been noted in infancy (Emery, 1955) and foetal life (Gruenwald, 1949; Emery, 1963) and have been related to the differing vascular pattern in intrauterine and in postnatal periods.

The connective tissue content of children's livers is significantly higher at all times and more marked in the left than in the right lobe (Ghosh and Emery, 1970), and it was suggested that the quantity of fibrous tissue might be related to the degree and duration of shock and hypoxia in the neonatal period and childhood. The present study was carried out in order to assess the possible effect of hypoxia on the production of hepatic fibrosis.

\section{Material and Methods}

It is customary in this hospital to take controlled sections from the left and right physiological lobes of the liver and the paired sections are filed serially. The slides are stained by Masson's trichrome. Three thousand five hundred paired sections were drawn out randomly, surveyed, and sections were selected which showed an obvious increase of connective tissue content and a distinct difference between the left and right lobes. Controls were selected by taking

Received for publication 20 December 1972. the next filed slide from a child who died at about the same age but whose liver showed no increase of connective tissue and no difference between the left and right lobes. Any necrosis and/or cirrhotic changes were carefully noted and further detailed microscopical studies were carried out on these cases to exclude any specific pathologies, eg, cystic fibrosis, fibrous hamartoma, or 'hepatitis'. Such cases were excluded.

Thus a total of 150 cases was selected without any knowledge of the clinical diagnosis and other necropsy findings. The assessments of the connective tissue and its ratio with liver parenchyma were made as in an earlier study (Ghosh and Emery, 1970). From this series the cases were divided into three groups according to the mean and percentile values of connective tissue content. Differences between the left and right lobes were also assessed.

Later the detailed clinical records, age at death, and postmortem protocol were noted of all the cases under study. The amount of cyanosis was assessed from the notes in the following way. If the baby was reported as normal and healthy and with no reduced Agpar score it was classified as 'no cyanosis'. If the child was noted to be cyanosed at birth and this persisted throughout life and was associated with a gross anatomical lesion at necropsy it was classified as 'prolonged and severe'. Children showing transient cyanosis were placed in the intermediate group. The associated pathological conditions and average age death of the children studied are shown in table I. 


\begin{tabular}{|c|c|c|c|c|}
\hline \multirow[t]{2}{*}{ Disease } & \multicolumn{2}{|l|}{ Group A (Control) } & \multicolumn{2}{|l|}{ Groups $B+C$} \\
\hline & Number of Cases & Average Age at Death & Number of Cases & Average Age at Death \\
\hline $\begin{array}{l}\text { Stillbirth } \\
\text { Congenital cyanotic heart } \\
\text { Acyanotic congenital heart } \\
\text { Acute respiratory distress } \\
\text { Hydrocephalus \& meningomyelocele } \\
\text { Cerebral haemorrhage } \\
\text { Surgical abdomen } \\
\text { Natural cause } \\
\text { Prematurity } \\
\text { Liver disease? }\end{array}$ & $\begin{array}{c}4(11 \%) \\
1(3 \%) \\
2(5.7 \%) \\
7(20 \%) \\
2(5.7 \%) \\
4(11 \%) \\
3(9 \%) \\
10(29 \%) \\
2(6 \%)\end{array}$ & $\begin{array}{l}3 \mathrm{mth} \\
3 \mathrm{mth} \\
4.5 \mathrm{mth} \\
15 \mathrm{mth} \\
3.3 \mathrm{mth} \\
11 \mathrm{mth} \\
20 \mathrm{mth} \\
6.5 \mathrm{hr}\end{array}$ & $\begin{array}{l}7(6 \%) \\
22(19 \%) \\
2(1 \cdot 7 \%) \\
30(26 \%) \\
17(15 \%) \\
7(6 \%) \\
15(13 \%) \\
6(5 \%) \\
4(4.0 \%) \\
5(4.3 \%)\end{array}$ & $\begin{array}{c}4.4 \mathrm{mth} \\
3.5 \mathrm{mth} \\
4.0 \mathrm{mth} \\
13 \mathrm{mth} \\
3 \mathrm{mth} \\
9 \mathrm{mth} \\
18 \mathrm{mth} \\
12 \mathrm{hr} \\
63 \mathrm{mth}\end{array}$ \\
\hline Total & 35 & & 115 & \\
\hline
\end{tabular}

Table I Cause of death and/or associated pathological condition

\section{Results}

Of the 150 cases studied, 35 showed less than $4 \%$ of connective tissue (minimum) when expressed as percentage of the surface of the section, with no significant difference between two lobes (fig. 1), and these constitute control group A. Group B (44 cases) and group $C$ ( 71 cases) showed $4-5 \%$ and more than $5 \%$ of connective tissue respectively. In the last two groups the two lobes (fig. 2) differed distinctly in their connective tissue content.

Of the children in control group A, $80 \%$ had no cyanosis at birth (table II). In contrast, only $27 \%$ of cases in both groups $B$ and $C$ were free from cyanosis at birth. Only $8.5 \%$ of cases in group A suffered from prolonged hypoxia whereas in groups B and C 55 and $63 \%$ respectively of cases were so affected. The hypoxia was due to a variety of causes. When the

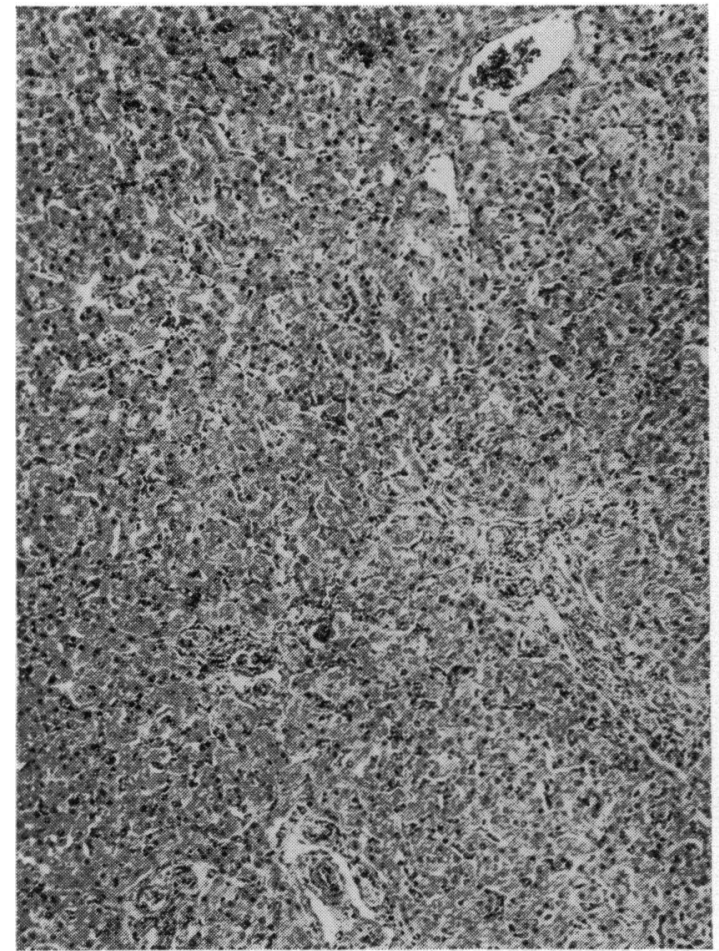

Left

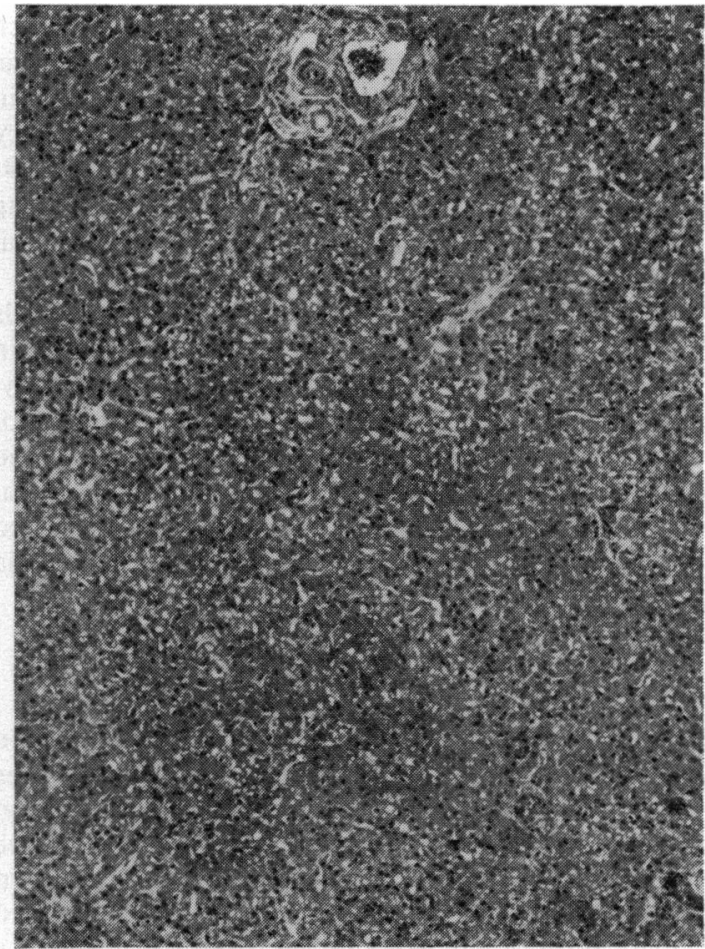

Right

Fig. 1 Photographs from the left and right lobes of a girl dying at the age of 8 months-unexpected death (cot death). Necropsy revealed minimal fibroelastosis and death followed a short incident of gastroenteritis. The child was reported to be completely healthy during infancy and the neonatal period $(H$ and $E \times 80)$. 


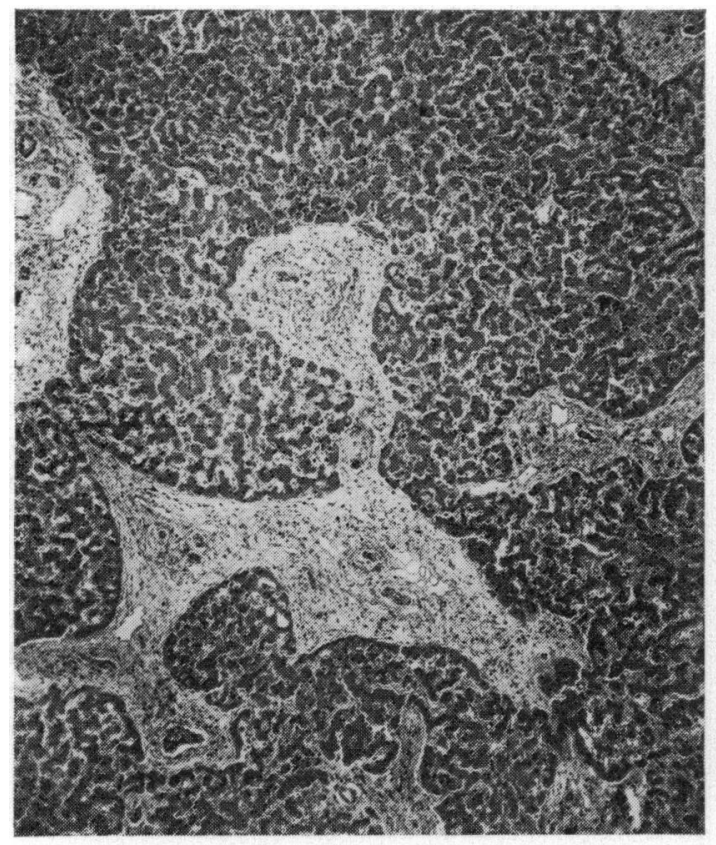

Left

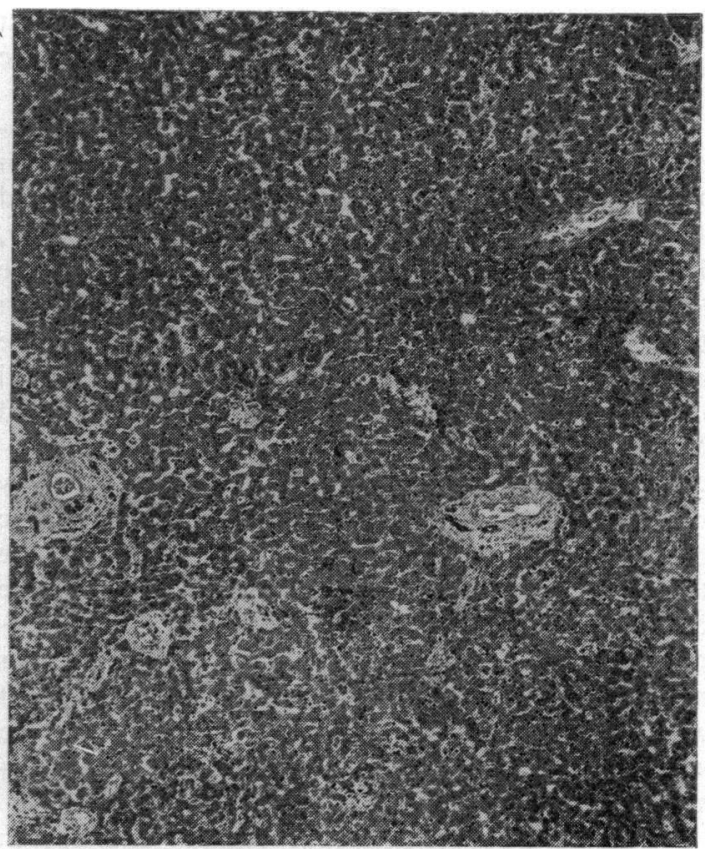

Right

Fig. 2 Photographs from the left and right lobes of a child dying at the age of 9 days. This child was born with a tracheo-oesophageal fistula for which she was operated on within three days of birth. Her condition steadily deteriorated to death and showed pulmonary changes $(H$ and $E \times 50)$.

\begin{tabular}{|c|c|c|c|c|c|c|c|c|c|}
\hline & \multicolumn{3}{|c|}{ Group A: Connective Tissue $<4 \%$} & \multicolumn{3}{|c|}{ Group B: Connective Tissue 4-5\% } & \multicolumn{3}{|c|}{ Group C: Connective Tissue $>5 \%$} \\
\hline & $\begin{array}{l}\text { No } \\
\text { Cyanosis }\end{array}$ & $\begin{array}{l}\text { Transient } \\
\text { Cyanosis at } \\
\text { Birth }\end{array}$ & $\begin{array}{l}\text { Prolonged } \\
\text { and Severe } \\
\text { Cyanosis }\end{array}$ & $\begin{array}{l}\text { No } \\
\text { Cyanosis }\end{array}$ & $\begin{array}{l}\text { Transient } \\
\text { Cyanosis at } \\
\text { Birth }\end{array}$ & $\begin{array}{l}\text { Prolonged } \\
\text { and Severe } \\
\text { Cyanosis }\end{array}$ & $\begin{array}{l}\text { No } \\
\text { Cyanosis }\end{array}$ & $\begin{array}{l}\text { Transient } \\
\text { Cyanosis at } \\
\text { Birth }\end{array}$ & $\begin{array}{l}\text { Prolonged } \\
\text { and Severe } \\
\text { Cyanosis }\end{array}$ \\
\hline No. of cases & $\begin{array}{l}28 \\
80 \%\end{array}$ & $11.5 \%$ & $\begin{array}{c}3 \\
8 \cdot 5 \%\end{array}$ & $\begin{array}{l}12 \\
27 \%\end{array}$ & $\begin{array}{c}8 \\
18 \%\end{array}$ & $\begin{array}{l}24 \\
55 \%\end{array}$ & $\begin{array}{l}19 \\
27 \%\end{array}$ & $\begin{array}{c}7 \\
10 \%\end{array}$ & $\begin{array}{l}45 \\
63 \%\end{array}$ \\
\hline Total & & 35 & & & 44 & & & 71 & \\
\hline
\end{tabular}

Table II Cyanosis and the ratio of connective tissue content

control group A was compared with groups B and C by the $\chi^{2}$ method, the difference was highly significant $(P<0.001)$ but there was no significant difference between groups $B$ and $C$ themselves. This indicated a significant correlation between incidence, degree, and duration of hypoxia, and the amount of connective tissue present in livers.

Two cases with longstanding hypoxia showed gross abnormality of the liver architecture with extreme fibrosis resembling cirrhosis. No definite cause was found in these cases from the clinical history and laboratory investigations except that one case was associated with a congenital heart lesion and the other had multiple small superficial cysts in the kidneys.

\section{Discussion}

The infant liver seems to be very sensitive to hypovolaemic shock and/or hypoxia and changes found in the two physiological lobes differ, depending on the timing of the shock, either during the intrauterine or postnatal period. The degenerative changes often seen in the left lobe of the liver in the newborn are thought to be due to sudden cutting off of the placental blood through the left liver (Emery, 1952). In contrast, right lobe necrosis occurs in intrauterine death or during the first day after birth (Daamen and Schaberg, 1969). Ghosh and Emery (1970) in a study of 200 livers from infant necropsies found a greater amount of connective tissue in the left as distinct 
from the right lobe. They thought that the most likely explanation was shock and hypoxia in the infants around the time of birth.

Parker in 1956 described six patients with congenital fibrosis of the liver whose ages ranged between 1 hour after birth to 33 years and which he regarded as a primary connective tissue anomaly. Similarly, Hardin (1965) reported two cases of fibrosis of the liver in children dying between 48 hours after birth to 16 years, where the exact cause could not be established from the clinical history and clinical investigations. Kerr, Harrison, Sherlock, and Milnes Walker (1961) described 13 cases of congenital hepatic fibrosis in young children which they regarded as a variant of congenital cystic disease causing portal hypertension due to deficiency in the terminal branches of the portal vein. In none of these cases was there any proven aetiology and no comparison of the right and left physiological lobes was made. The amount of fibrosis seen in some cases of congenital fibrosis is no greater than that seen in some children where shock or hypoxia are demonstrable factors.

There is a counterpart of similar changes in animal experiment. Swenson, Grana, Inouye, and Donnellan (1967) produced a variety of changes in dogs' livers due to hypoxia by cutting off the hepatic blood supply for differing durations. The predominant changes were increased fibrous tissue in the left lobe and, in some cases, the changes were similar to cirrhosis. These changes mimic almost exactly those seen in the newborns studied in this present series. The children who suffered from transient asphyxia had minimum increase of fibrous tissue whereas those who had hypoxia for over several months associated with congenital heart or other deformities showed the highest amount of connective tissue.

There were also some cases of necrosis and changes resembling cirrhosis which had prolonged hypoxia associated with congenital cyanotic heart disease, coarctation of the aorta, cystic kidneys, and acute respiratory distress, but no other explanation was found in this group from the clinical history or other investigations. Shiraki (1970), in a parallel study of
146 infants dying from birth to 7 days of age, noted hepatic necrosis in $24.5 \%$ and fatty changes in a further $14.3 \%$ of cases. He concluded that hypoplastic left heart complex and coarctation of the aorta were more frequently associated with hepatic necrosis than with any other type of congenital heart disease.

The present study indicates a definite correlation between the presence of increased hepatic connective tissue or fibrosis and prolonged severe hypoxia. The common anomalies found in the cases with most connective tissue were congenital cyanotic heart disease, coarctation of the aorta, acute respiratory distress, central nervous system abnormality, and surgical abdominal conditions with postoperative shock. Thus it appears that hypoxia during the neonatal period is an important factor in producing hepatic fibrosis, particularly where the hypoxia was severe, of long duration, and associated with circulatory disturbance. It is important that, in any liver in a child showing an increase in fibrous tissue, the perinatal state of the child be explored.

\section{References}

Cantlie, J. (1897-1898). On a new arrangement of the right and left lobes of the liver. J. Anat. (Lond.), 32, iv-ix.

Daamen, C. B. F., and Schaberg, A. (1969). Hemilateral liver degeneration in perinatal death. J. Path., 97, 29-34.

Emery, J. L. (1952). Degenerative changes in the left lobe of the liver in the newborn. Arch. Dis. Childh., 27, 558-561.

Emery, J. L. (1955). Asymmetrical liver disease in infancy. J. Path. Bact., 69, 219-224.

Emery, J. L. (1963). Functional asymmetry of the liver. Ann. N.Y. Acad. Sci., 111, 37-42.

Ghosh, M. L., and Emery, J. L. (1970). The connective tissue in livers of children. J. clin. Path., 23, 599-603.

Gruenwald, P. (1949). Degenerative changes in the right half of the liver resulting from intra-uterine anoxia. Amer. J. clin. Path., 19, 801-813.

Hardin, C. A. (1965). Congenital hepatic fibrosis. Arch. Surg., 91, 884886.

Kerr, D. N. S., Harrison, C. V., Sherlock, S., and Milnes Walker, R. (1961). Congenital hepatic fibrosis. Quart. J. Med., 30, 91-117.

Mall, F. P. (1906). A study of the structural unit of the liver. Amer.J. Anat., 5, 227-308.

Parker, R. G. F. (1956). Fibrosis of the liver as a congenital anomaly. J. Path. Bact., 71, 359-368.

Shiraki, K. (1970). Hepatic cell necrosis in the newborn. Amer. J. Dis. Childh., 119, 395-400.

Swenson, O., Grana, L., Inouye, T., and Donnellan, W. L. (1967). Immediate and long-term effects of acute hepatic ischemia. Arch. Surg., 95, 451-463. 